\section{Neonatal colisepticemia in a dog - a case report}

\author{
Colissepticemia neonatal em um canino - relato de caso
}

\author{
Taina dos Santos Alberti ${ }^{*}$, Josiane Bonel², Fabiano da Rosa Venancio ${ }^{3}$, Cristiano Silva da Rosa ${ }^{4}$, Silvia Leal \\ Ladeira² $\&$ Daniela Isabel Brayer Pereira $^{5}$ \\ 'Veterinary Medicine, Master. Programa de Pós-graduação em Veterinária, Universidade Federal de Pelotas - UFPel, Pelotas, \\ RS, Brasil \\ ${ }^{2}$ Veterinary Medicine, Dra. Departamento de Patologia Animal, Faculdade de Veterinária, Universidade Federal de Pelotas - \\ UFPel, Pelotas, RS, Brasil \\ ${ }^{3}$ Veterinary Medicine, Residente. Programa de Residência Multiprofissional em Área Profissional da Saúde - Patologia Animal, \\ Universidade Federal de Pelotas - UFPel, Pelotas, RS, Brasil \\ ${ }^{4}$ Veterinary Medicine, Dr. Laboratório Regional de Diagnóstico, Faculdade de Veterinária, Universidade Federal de Pelotas - \\ UFPel, Pelotas, RS, Brasil \\ ${ }^{5}$ Veterinary Medicine, Dra. Departamento de Microbiologia e Parasitologia, Instituto de Biologia, Universidade Federal de \\ Pelotas - UFPel, Pelotas, RS, Brasil
}

\section{Resumo}

Escherichia coli é uma bactéria Gram-negativa, pertencente a microbiota comensal do trato gastrointestinal dos animais e humanos.Algumas cepaspossuem fatores de virulência, podendo causar enterite e/ou septicemia. Na forma septicêmica da doença, o principal fator predisponenteé a não ingestão ou ingestão de quantidades insuficientes de colostro.O objetivo deste trabalho é relatar um caso de colissepticemia neonatal em um canino de cinco dias de idade. Na necropsia do cadáver foi observado congestão nos órgãos das cavidades abdominal e torácicae áreas esbranquiçadas multifocais a coalescentes nos rins e pulmão. No exame histopatológico do rim, fígado, pulmão e coração observou-se áreas multifocais de necrose com presença de miríades bacterianas intralesionais. Nas amostras de órgão encaminhadas para o diagnóstico microbiológico houve crescimento de E. coli. O histórico clínico, bem como os achados histopatológicos e microbiológicos permitem inferir que a causa mortis foi decorrente de um quadro de septicemia por E. coli.

Palavras-chave: filhotes, Escherichia coli, septicemia, caninos.

\begin{abstract}
Escherichia coli is a gram-negative bacterium belonging to the commensal microbiota of the gastrointestinal tract of animals and humans. Some strains present virulence factors, which can lead to enteritis and/or septicemia. In the septicemic form of the disease, the main predisposing factor is the lack of ingestion or the insufficient ingestion of colostrum. The aim of this study was to report a case of neonatal colisepticemia in a five-day-old puppy. At necropsy, congestion was observed in organs of the abdominal and thoracic cavities as well as whitish multifocal, coalescing areas in the kidneys and lungs. Histopathological examination of the kidneys, liver, lungs and heart showed multifocal areas of necrosis with intralesional bacterial myriads. The organ samples sent for microbiological diagnosis showed $E$. coli growth. The clinical history, as well as histopathological and microbiological findings, allowed us to infer that death was due to sepsis caused by E. coli.
\end{abstract}

Keywords: puppies, Escherichia coli, septicemia, dogs.

\section{Introduction}

Escherichia coli (E.coli) is a bacterium belonging to the Enterobacteriaceae family, which is classified as a facultative, non-spore forming Gram-negative bacillus or coccobacillus. The majority of E. coli strains are nonpathogenic agents belonging to commensal microbiota of the intestine, but some carry virulence factors, such as fimbrial adhesins, capsules, endotoxins, enterotoxins and cytotoxins, which are potentially pathogenic. The occurrence of infections depends on factors related to the environment, management and immune status of the animals (Guedes et al., 2016; Quinn et al., 2005; Osman et al., 2013).

Infections caused by bacteria of the genus Escherichia can manifest in two distinct forms, enteric or septicemic. The enteritis picture by $E$. coli is characterized by the presence of profuse
How to cite: Alberti, T. S., Bonel, J., Venancio, F. R., Rosa, C. S., Ladeira, S. L. \& Pereira, D. I. B. (2019). Neonatal collissepticemia in canine - a case report. Brazilian Journal of Veterinary Medicine, 41, e97019. doi: 10.29374/2527-2179. bjvm097019

\section{Financial support: None}

Conflict of interests: No conflict of interests declared concerning the publication of this article.

Received: July 03, 2018.

Accepted: February 03, 2019

The study was carried ou at Laboratório Regional de Diagnóstico - LRD, Universidade Federal de Pelotas - UFPel, Pelotas, RS, Brasil.

\section{*Correspondence}

Taina dos Santos Alberti

Departamento de Patologia Animal,

Universidade Federal de Pelotas - UFPEL

Campus Capão do Leão, s/n

CEP 96015-560 - Capão do Leão (RS), Brasil

E-mail: taina_alberti@yahoo.com 
diarrhea, severe dehydration, acidosis and death within a few days (Coura et al., 2014). In sepsis, many of the clinical signs are attributed to the action of the endotoxin and can manifest as fever, depression, weakness and tachycardia with or without diarrhea (Quinn et al., 2005).

In the septicemic infection caused by $E$. coli (colisepticemia) the main gateways are the oral cavity, respiratory system and navel (Howard, 2013). In the bloodstream, the bacterium multiplies rapidly and spreads through bacterial emboli to all tissues, surviving the complement effect, phagocytosis and phagocyte intracellular lysis (Magalhães et al., 1991).

Neonatal colisepticemia is related to the neonate immunological competence, as well as to the contamination of the environment to which the animals are exposed. Failure to ingest or the ingestion of insufficient amounts of colostrum is the main predisposing factor for the development of sepsis by $E$. coli, since the animals do not have immunity to fight infections. This pathology is often described in calves and pigs and more rarely in colts that did not ingest colostrum (Howard, 2013). In dogs and cats colisepticemia is mainly related to a immunological incompetence of neonates rather than the virulence of the $E$. coli involved in the disease (Greene \& Marks, 2015). The aim of this study was to report a case of neonatal colisepticemia in a puppy.

\section{History}

The carcass of a five-day-old female Cocker from a kennel located in the municipality of Pelotas, $\mathrm{RS}$, Brazil, was referred to the pathology laboratory. According to the Veterinarian in charge, the patient did not show previous clinical symptoms but only presented a delay in its development in relation to the other puppies in the litter. On the fifth day of life, the puppy died, having had a cardiorespiratory arrest.

The necropsy was performed at the Pathology Department, when fragments of the organs of the abdominal, thoracic and brain cavities were collected and fixed in $10 \%$ formalin. After 48 hours, organ fragments were cleaved, paraffin embedded, cut into 3 micron sections and stained by the Hematoxylin and Eosin (HE) routine technique and Gram staining. Fragments of the liver, lungs, kidneys and swabs from the abdominal and thoracic cavities were also collected and immediately sent to the bacteriology laboratory for culture in $5 \%$ sheep blood agar and MacConke Agar. The identification of the bacterium was performed as described by Quinn et al. (2005).

At necropsy, intense congestion of the organs of the abdominal and thoracic cavities was observed. In the lungs there were multifocal whitish areas distributed on the pleural surface and in the parenchyma of the organ. In the kidneys, multifocal, coalescing whitish areas were also observed on the subcapsular and cut surfaces (Figure1). In the samples of organs and cavity swabs sent to the bacteriology laboratory, there was growth of gray, non-hemolytic colonies in blood agar and pink, mucoid colonies with precipitation of bile salts in MacConkey agar. In gram

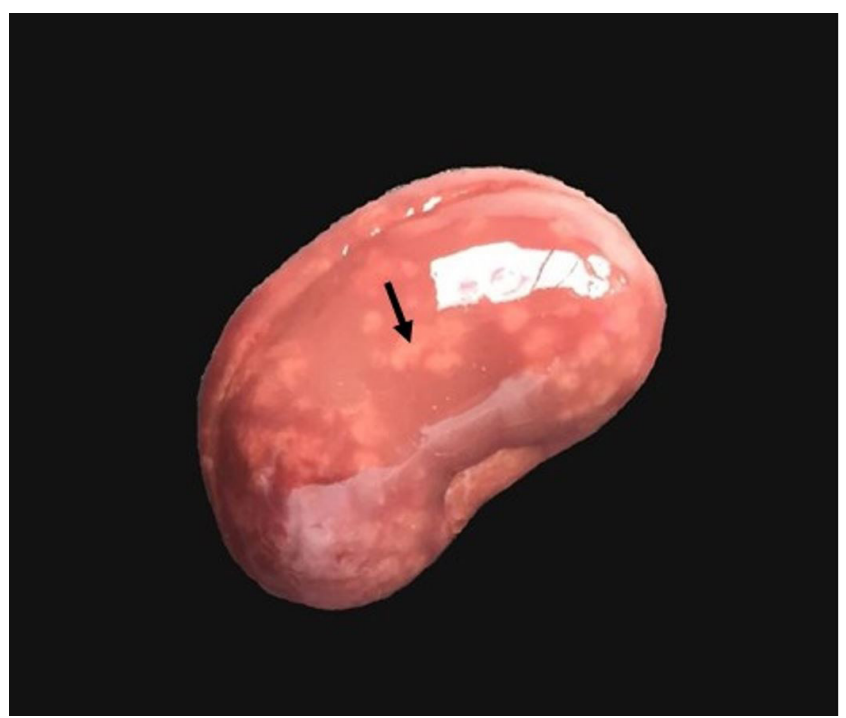

Figure 1. Kidney showing multifocal to coalescing whitish areas (arrow). 
staining, gram-negative coccobacilli and catalase positive reaction (+) were observed. In the biochemical characterization, the bacteria showed nitrate + , citratonegative (-), indole +, hydrogen sulphide, motile + and mannitol and maltose + . From the characteristics of the colony and Gram and biochemical tests, the bacterium was characterized as Escherichia coli.

The histopathological examination of the lungs by hematoxylin and eosin (HE) staining evidenced intense pulmonary edema, thickening of alveolar septa, multifocal areas of necrosis with the presence of bacterial myriads and inflammatory infiltrate consisting predominantly of lymphocytes and plasma cells (Figure 2A). In the visceral pleura, areas of necrosis and bacterial colonies were also observed (Figure 2B). There were multifocal areas of necrosis in the kidneys with intense inflammatory mononuclear cell infiltrate and the presence oh intralesional bacteria, as well as bacterial thrombi and emboli, vasculitis and haemorrhage (Figure 2C and 2D). Bacterial colonies were also observed in the liver and heart, along with an inflammatory infiltrate of mononuclear cells. Gram staining showed colonies of Gram-negative bacteria in the kidneys, lungs, liver and heart (Figure 3).
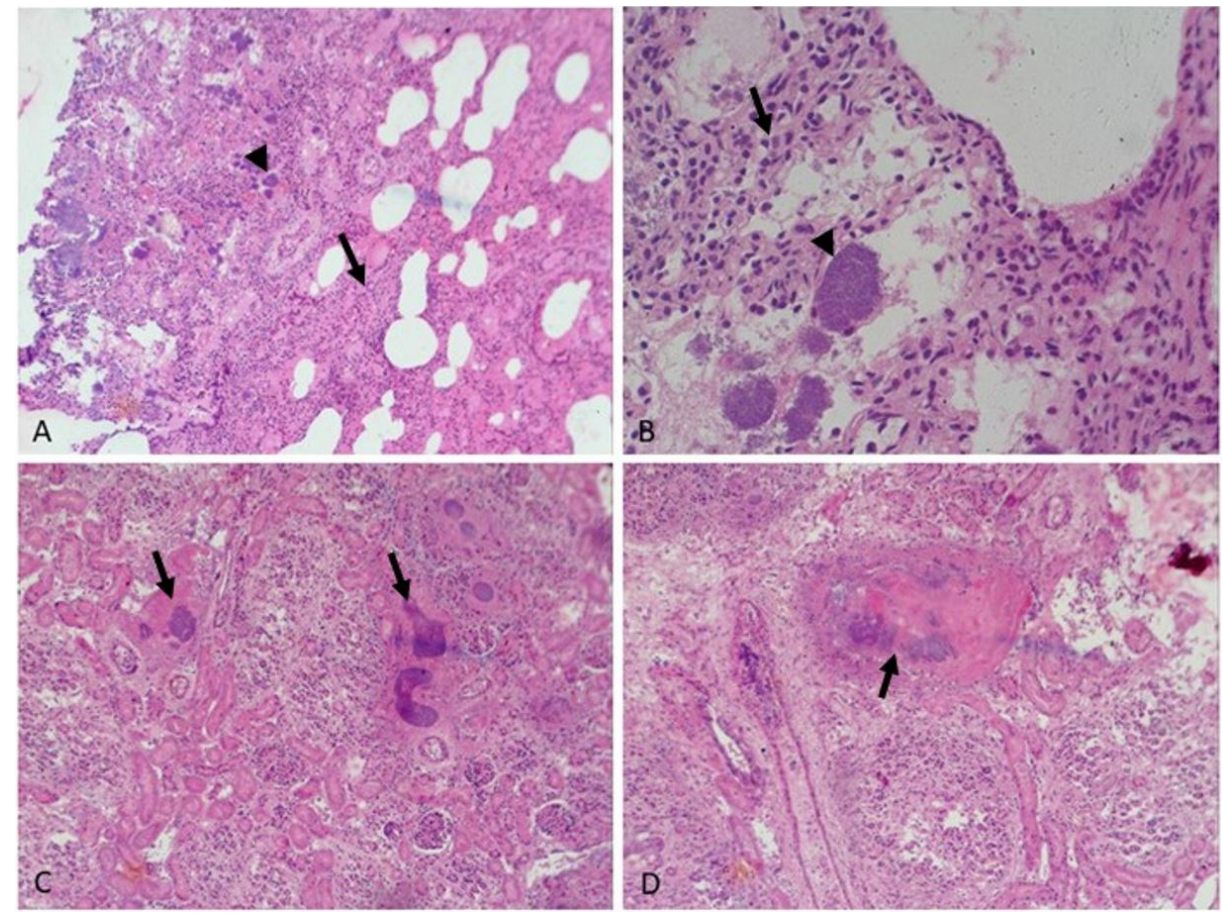

Figure 2. Hematoxylin and Eosin (HE) staining. A) Lung showing septal thickening (arrow), necrotic area with bacterial myriads (arrowhead) (4x). B) Lung showing septal thickening (arrow), necrosis and bacterial myriads (arrowhead) (10x). C) Kidney showing multifocal necrosis areas and intralesional bacterial myriads (arrows) (4x). D) Kidney, blood vessel with thrombus and bacterial emboli (arrows) (10x).

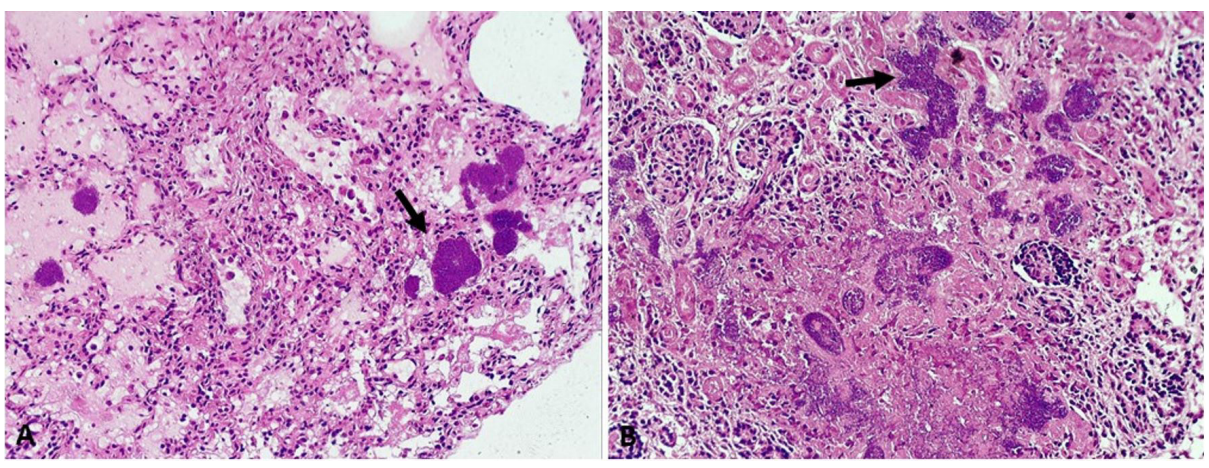

Figure 3. Gram staining. A) Lung. Notice the presence of Gram-negative coccobacilli myriads (arrow) (10x). B) Kidney: Presence of Gram-negative coccobacilli amongst necrotic areas (arrow) (10x). 


\section{Discussion}

Neonatal colisepticemia is a sporadic disease, described mainly in cattle (Gay, 2013). It primarily affects animals in the first week of life, between the second and fifth day, and may occur until the second week, having a high mortality rate. In all affected species it is observed that the main determinant for the occurrence of the disease is a failure in passive immunity transmission (Gay, 2013).

Sepsis by E. coli is manifested as an acute disease, usually without apparent clinical manifestations, causing the death of the animal within a few days (Rengifo et al., 2006). In the initial stages of the disease, non-specific signs such as pyrexia, depression, weakness, tachycardia, and diarrhea may be present. In the final stage of the disease, the animal may present hypothermia and prostration (Quinn et al., 2005). In the present case there were no clinical manifestations.

In calves, pigs and horses, colisepticemia occurs in the first days of life in newborns that have not ingested colostrum (Reck, 2009; Howard, 2013). In the present report, the animal was five days old, which shows that the evolution of neonatal colisepticemia is similar in different species, and that the main reason for the development of the disease in small animals may also be related to lack or insufficient ingestion of colostrum by the animal, since in this case only one of the five puppies presented the disease.

The bacterium is eliminated by the nasal, oral, urine and faece secretions, and the animal begins to discharge it in the preclinical stage of the disease. Infection occurs through the contaminated environment (Gay, 2013; Guedes et al., 2016). The animal referred to the LRD came from a kennel, which is a predisposing factor, since the degree of environmental contamination in kennels is greater due to the confinement of the animals in a restricted environment.

In infections with the most virulent strains of $E$. coli, subclinical bacteremia first occurs, followed by sepsis and dealth by endotoxemic shock. In cases of infection with less virulent strains, the clinical course is longer, and localized infections such as polyarthritis, meningitis and occasionally uveitis and nephritis may occur. The chronic form of the disease occurs in animals that have basal levels of circulating immunoglobulin (Gay, 2013). In the reported case the clinical picture was fast, without the development of previous clinical signs, which suggests that the involved strain presented high virulence.

According to Howard (2013), the presence of cortical abscesses in the kidneys is the main macroscopic finding in sepsis. After reaching the bloodstream, E. coli multiplies rapidly, spreading to all organs, especially the kidneys. In the reported case, the main macroscopic lesions were observed in the kidneys.

The main histopathological findings in E. coli cases of sepsis in calves were characterized by the dissemination of the bacterium to the tissues through metastatic mechanisms, when bacterial colonies were observed in the interior of blood vessels amidst necrotic foci (Magalhães et al., 1991). In this report, the lesions were characterized by the presence of Gram negative bacterial myriads in necrotic areas and inside blood vessels.

In the present report $E$. coli was isolated from the lungs, liver, kidneys and cavity swabs. Similar results were reported by Marietto-Gonçalves et al. (2007) in a colisepticemia case in a True Parrot (Amazona aestiva), where E. coli colonies were isolated from various organs (heart, lungs, liver and a caseous mass was removed from the air sacs), thus confirming the dissemination of the bacterium into various tissues.

\section{Conclusion}

Neonatal colisepticemia is a rarely diagnosed pathology, and no reports of the disease in dogs have been found, which may be related to the fact that the majority of puppies are referred for disposal rather than necropsy. Thus, the present report points to the importance of performing the post-mortem diagnosis.

\section{Referências}

Coura, F. M., Lage, P. A., \& Heinemann, M. B. (2014). Patotipos de Escherichia coli causadores de diarreia em bezerros: uma atualização. Pesquisa Veterinária Brasileira, 34(9), 811-818. http://dx.doi.org/10.1590/ $\underline{\text { s0100-736X2014000900001. }}$ 
Gay, C. C. (2013). Infecções generalizadas. In C. M. Khan (Ed.), Manual Merck (pp. 625-857). São Paulo: Roca.

Greene, C. E., \& Marks, S. L. (2015). Infecções gastrointestinais e intra-abdominais. In C. E. Greene (Ed.), Doenças Infecciosas em cães e gatos (pp. 989-1020). Rio de Janeiro: Roca.

Guedes, R. M. C., Brown, C. C., Sequeira, J. L., \& Reis, J. L. (2016). Sistema digestório. In R. L. Santos \& A. C. Alessi (Eds.), Patologia veterinária (pp. 155-157). Rio de Janeiro: Roca.

Howard, B. G. (2013). Sistema Alimentar, Peritônio, Omento, Mesentério e Cavidade Peritoneal. In M. D. McGavin \& J. F. Zachary (Eds.), Bases da Patologia em veterinária (pp. 324-406). Rio de Janeiro: Elsevier.

Magalhães, H., Freitas, M. A. Q., Gonçalves, W. D., Santos, J. Á., Medeiros, M. I. M., Costa, C. H. C., \& Vollu, E. W. (1991). Ocorrência, aspectos bacteriológicos e histopatológicos na colibacilose de bezerros. Pesquisa Agropecuária Brasileira, 26(4), 555-564.

Marietto-Gonçalves, G. A., Lima, E. T., Sequeira, J. L., \& Andreatti, F. R. L. (2007). Colisepticemia em Papagaio verdadeiro (Amazona aestiva). Revista Brasileira de Saúde e Produção Animal, 8(1), 56-60.

Osman, K. M., Mustafa, A. M., Elhariri, M., \& Abdelhamed, G. S. (2013). A distribuição de Escherichia coli serovars, genes de virulência, associação de gêneros e combinações e genes de virulência codificando serótipos em e. coli patogênica recuperada de vitelas diarróicas, ovinos e cabras. Transboundary and Emerging Diseases, 60, 69-78. http://dx.doi.org/10.1111/j.1865-1682.2012.01319.x. PMid:22435607.

Quinn, P. J., Markey, B., Carter, M. E., Donnelly, W. J. C., \& Leonard, F. C. (2005). Microbiologia veterinária e doenças infecciosas (pp. 512). Porto Alegre: Art Med.

Reck, M. V. M. (2009). Diarreia Neonatal Bovina (Monografia). Universidade Federal do Rio Grande do Sul, Porto Alegre, $12 \mathrm{p}$.

Rengifo, S. A., Silva, R. A., Pereira, I. A., Zegarra, J. Q., Souza, M. M. \& Botteon, R. C. C. M. (2006). Isolamento de agentes microbianos a partir de amostras de sangue e umbigo de bezerros mestiços neonatos. Brazilian Journal of Veterinary Research and Animal Science, 43(4), 442-447. 